\title{
Anemia and the outcomes in renal transplant recipients: a meta- analysis
}

\author{
Huang Gang ${ }^{1}$, Li Jun ${ }^{1}$, Chen Guodong ${ }^{1}$, Chen Lizhong ${ }^{1}$ and Qiu Jiang ${ }^{1}$ \\ ${ }^{1}$ Division of Organ Transplantation, The First Affiliated Hospital of Sun Yat-Sen University, Guangzhou 510080, China
}

Correspondence to: Qiu Jiang, email: qiujiangdoc@163.com

Keywords: anemia, kidney transplantation, creatinine, graft loss rate, all-cause death rate

Received: April 23, $2017 \quad$ Accepted: August 17, $2017 \quad$ Published: December 06, 2017

Copyright: Gang et al. This is an open-access article distributed under the terms of the Creative Commons Attribution License 3.0 (CC BY $3.0)$, which permits unrestricted use, distribution, and reproduction in any medium, provided the original author and source are credited.

\section{ABSTRACT}

Background: The impact of anemia on graft loss rate and all-cause death rate remains controversial in renal transplant recipients. We performed a meta-analysis to explore the influence of anemia correction on the outcomes in renal transplant recipients.

Materials and Methods: We searched PubMed and EMBASE databases from January 1st 1981 to December 31st, 2016 to identify potential studies assessing the impact of anemia on kidney transplantation. Fixed or random effect model was used according to the heterogeneity. Potential heterogeneity was checked by sensitivity analysis and meta-regression analysis.

Results: A total of 9 randomized controlled trials with 1387 participants (mean age ranged from 39 to 53 years) were included. Our results showed that anemia correction significantly decreased the creatinine level (WMD $0.52 \mathrm{mg} / \mathrm{dl} ; 95 \% \mathrm{CI}$ : $0.12,0.92 ; P=0.011)$, graft loss rate $(0.07,95 \% \mathrm{CI}: 0.05,0.08 ; P<0.0001)$ and allcause death rate $(0.01,95 \% \mathrm{CI}: 0.00,0.01 ; P=0.023)$. Furthermore, comparing with control group, erythropoietin (EPO) treatment greatly decreased creatinine level in renal transplant recipients (WMD $1.15 \mathrm{mg} / \mathrm{dl} ; 95 \% \mathrm{CI}: 0.27,2.03 \mathrm{vs}$. WMD $0.05 \mathrm{mg}$ / dl; 95\% CI: $-0.13,0.23 ; P<0.0001$ ).

Conclusions: Our findings showed that anemia correction reduced creatinine level, graft loss rate and all-cause death rate in renal transplant recipients. And EPO treatment is a good choice for anemia correction in renal transplant recipients.

\section{INTRODUCTION}

Anemia is a common complication of chronic kidney disease (CKD). And even after kidney transplantation, there is still a high prevalence $(20 \%$ to $60 \%)$ of anemia [1]. It has been demonstrated that anemia is associated with cardiovascular death in patients with CKD [2] and poor long-term survival after kidney transplantation [3]. However, the impact of anemia on graft loss rate and all-cause death rate remains controversial in kidney transplantation $[4,5]$. The findings from the ALERT study showed that post-transplantation anemia was not associated with an increased incidence of cardiovascular morbidity and mortality or all-cause mortality [5].

A series of cause have been demonstrated to be related with anemia in patients with kidney transplantation including chronic prescription of immunosuppressive drugs, antihypertensive drug angiotensin-converting enzyme inhibitors and angiotensin-receptor blockers, impaired kidney allograft function and etc $[6,7]$. In clinic practice, erythropoietin (EPO) treatment and intravenous or oral iron treatment are the main primary ways to cure anemia in renal transplant patients. Previous studies demonstrated that anemia correction with EPO treatment reduced the postoperative requirement for blood transfusions and had no deleterious effects on kidney graft function in renal transplant recipients [8]. However, other studies found that a high dose EPO treatment had no effects on long-term graft functions [9].

Since the role of anemia and EPO treatment in renal transplant recipients are controversial, we perform a metaanalysis of randomized controlled trials (RCTs) to evaluate the impact of anemia correction and EPO treatment on the outcomes of renal transplant recipients. 


\section{MATERIALS AND METHODS}

\section{Search strategy}

We conducted a comprehensive search on studies on anemia and kidney transplantation published between January 1st 1981 to December 31st, 2016 in the PubMed and Embase databases. Search keywords were: "kidney transplantation", "renal transplantation", "kidney transplant", "anemia", "anaemia", and "anemic". We also searched for additional articles from the selected literatures to find other potentially related studies.

\section{Study selection}

Selection criteria for inclusion in the meta-analysis were as following: (1) type of study design should be RCTs; (2) only publications written in English were considered; (3) the age of the patients with kidney transplantation were older than 18 years; (4) met the anemia criteria: mean hemoglobin levels $<120 \mathrm{~g} / \mathrm{L}$ according to WHO definition of anemia $(<120 \mathrm{~g} / \mathrm{L}$ for women and $<130 \mathrm{~g} / \mathrm{L}$ for men).

\section{Data extraction}

Two investigators independently extracted the data. Discrepancies were resolved by consensus. The following data were extracted: names of the authors, name of the journal, publication year, sample size, mean age, followup intervals, hemoglobin level, creatinine level, type of EPO use, number of graft loss, and number of all-cause death.

\section{Assessment of study quality}

Two investigators independently assessed the validity of the studies using the Jadad Score [10]. The Jadad score assesses randomisation, blinding, and attrition to derive a score ranging from 0 (low quality) to 5 (high quality).

\section{Statistical analysis}

A meta-analysis was performed using Stata version 12.0 (Stata Corp,College Station, TX, USA). Each RCT was composed of two or more treatment arms, and each type of treatment was taken as a separate observation [11]. We used fixed- or random-effects models in the absence or presence of heterogeneity among studies. The statistical heterogeneity across studies was assessed using $\mathrm{I}^{2}$ statistic where an $\mathrm{I}^{2}>50 \%$ is considered to exist significant heterogeneity. As for continuous outcomes, results were presented as weighted mean difference (WMD) and 95\% confidence interval (CI). Proportions were converted to a natural logarithmic scale. The delta method was used to calculate standard errors for proportions [12]. Then statistical pooling of odds ratios and proportions were calculated by Stata. The unpaired $t$-test was used to make comparisons between groups. If there was a high degree of heterogeneity, we subsequently conducted sensitivity analysis by removing studies one at a time to determine whether a particular study was responsible for the heterogeneity. Moreover, we also used meta-regression analysis to analyze the possible sources of heterogeneity. Publication bias was evaluated using funnel plots, Begg test and Egger test. Statistical significance was defined at $P<0.05$.

\section{RESULTS}

\section{Eligible studies}

We identified 111 studies from the potentially relevant published literatures and retrieved 44 studies for further evaluation. At last, only 9 studies [13-21] met the inclusion criteria for final evaluation. The flow chart for the study selection was shown in Figure 1.

\section{Baseline characteristics}

The baseline characteristics of the 9 studies were shown in Table 1. A total of 1387 participants with a mean age ranged from 39.0 to 53.0 years were identified. In the identified studies, sample size range was 40 to 833 . And mean follow-up interval was 2 to 24 months. The mean hemoglobin level range at baseline was $83.0 \mathrm{~g} / \mathrm{L}$ to 111.0 $\mathrm{g} / \mathrm{L}$. Most studies (6 of 9) use erythropoietin (EPO) for anemia treatment. The mean creatinine level at baseline ranged from $1.2 \mathrm{mg} / \mathrm{ml}$ to $3.7 \mathrm{mg} / \mathrm{ml}$.

\section{Anemia correction decreased creatinine level in renal transplant recipients}

We found that the mean hemoglobin level was increased in each study (Table 1). So we firstly explored creatinine level in the whole renal transplant recipients with anemia improvement. The result showed that creatinine level was significant decreased accompanied with anemia improvement (WMD $0.65 \mathrm{mg} / \mathrm{dl} ; 95 \% \mathrm{CI}$ : $0.19,1.11 ; P=0.005$ ) (Figure 2). Then we grouped the studies according to the hemoglobin level at the end of each study: anemia correction group (hemoglobin level $>120 \mathrm{~g} / \mathrm{L}$ ) and anemia persist group (hemoglobin level $<120 \mathrm{~g} / \mathrm{L}$ ). And we found that anemia correction group significantly decreased creatinine level (WMD 0.52 $\mathrm{mg} / \mathrm{dl} ; 95 \%$ CI: $0.12,0.92 ; P=0.011$ ) (Figure 3). More interestingly, although anemia persist group decreased more creatinine level than anemia correction group, it was not significant (WMD $0.67 \mathrm{mg} / \mathrm{dl}$; 95\% CI: $-0.03,1.36$; $P=0.061$ ) (Figure 3). Moreover, mean hemoglobin level elevated in both groups because of most studies using 
EPO (anemia persist group from $88.3 \mathrm{~g} / \mathrm{L}$ to $100.6 \mathrm{~g} / \mathrm{L}$; anemia correction group from $98 \mathrm{~g} / \mathrm{L}$ to $126.8 \mathrm{~g} / \mathrm{L}$ )

\section{EPO treatment decreased creatinine level in renal transplant recipients}

To further explore the effect of EPO treatment on creatinine level in renal transplant recipients, we divided the studies into EPO treatment group and Control group. It was showed that EPO treatment group significantly decreased creatinine level in renal transplant recipients comparing with control group (WMD $1.15 \mathrm{mg} / \mathrm{dl}$; 95\% CI: $0.27,2.03$ vs. WMD $0.05 \mathrm{mg} / \mathrm{dl}$; 95\% CI: $-0.13,0.23$; $P<0.0001$ ) (Figure 4).

\section{Graft loss rate in renal transplant recipients}

Since graft loss rate associates with the poor prognosis of patients with kidney transplantation, we evaluated graft loss rate in renal transplant recipients. We found the whole graft loss rate was 0.06 (95\% CI: 0.04 , 0.09) (Figure 5). Then we explored the effect of anemia correction on graft loss rate, the results showed that anemia correction group had a significant lower graft loss rate than anemia persist group $(0.07,95 \% \mathrm{CI}: 0.05,0.08 \mathrm{vs}$. 0.08, 95\% CI: $0.01,0.15 ; P<0.0001$ ) (Figure 5).

\section{All-cause death rate in renal transplant recipients}

We also evaluated the all-cause death rate in renal transplant recipients. It was found that the all-cause death rate was 0.01 (95\% CI: 0.00, 0.02) (Figure 6). Moreover, compared with anemia persist group, anemia correction group had a significant lower all-cause death rate $(0.01$, 95\% CI:0.00, 0.01 vs. 0.03, 95\% CI: $0.01,0.05 ; P<$ 0.0001 ) (Figure 6).

\section{Determinants of statistical heterogeneity and publication bias}

Firstly, we used sensitivity analysis to explore statistical heterogeneity. We removed studies one at a time to assess which study was accounted for the high heterogeneity. However, we found no single study fully explained for the heterogeneity (Supplementary Figure 1). Then we used meta-regression analysis to further explore the statistical heterogeneity. We only found hemoglobin and creatinine at baseline significantly contributed to the heterogeneity among studies (hemoglobin, $P=0.008$; creatinine, $P<0.0001)$. When we explored for potential publication bias, the funnel plot did not appear asymmetrical (Figure 7), and both Begg and Egger tests

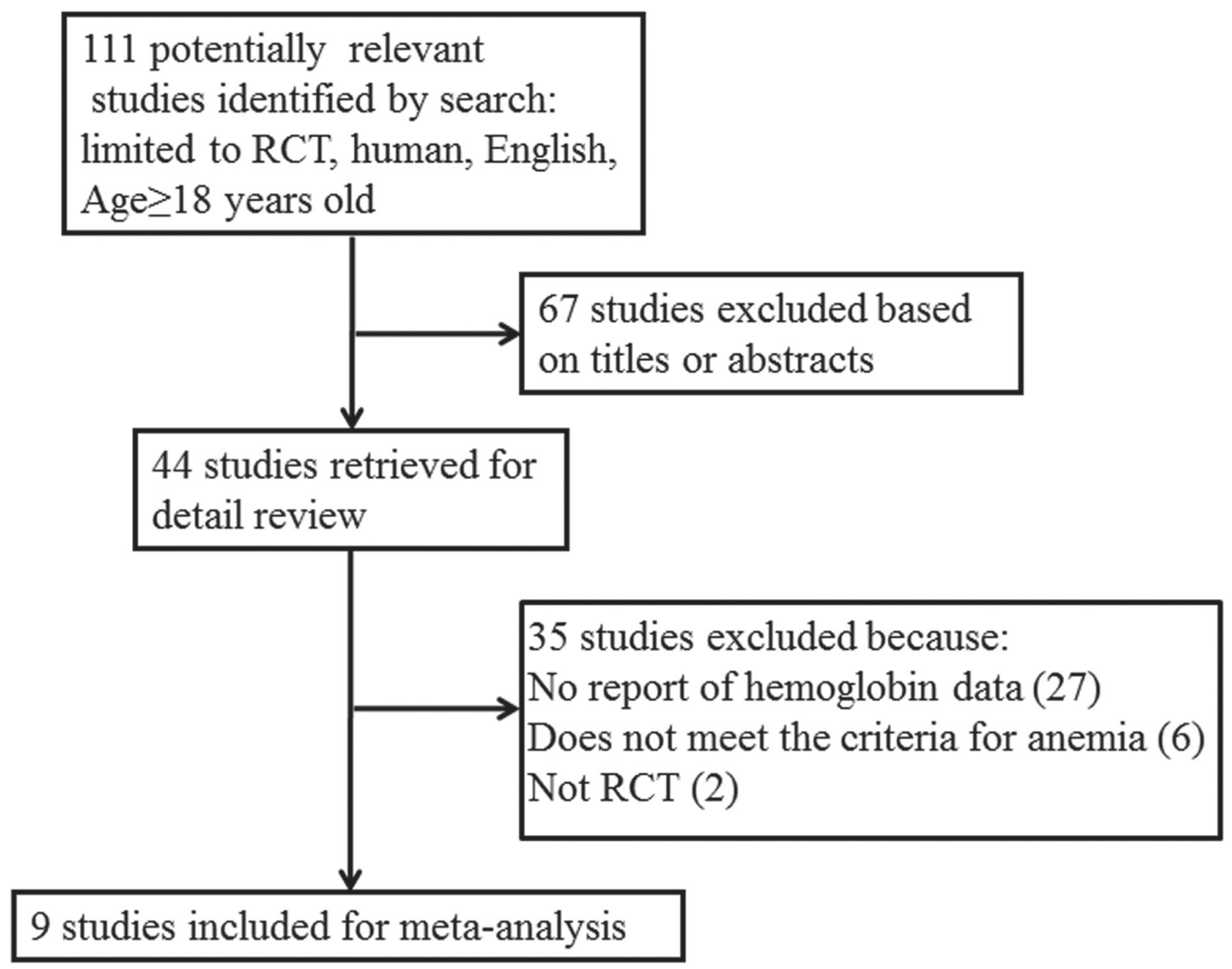

Figure 1: Search flow diagram for studies included in the meta-analysis. RCT, randomized controlled trial. 
Table 1: Baseline characteristics of enrolled study population in 9 RCTs $(n=1387)$

\begin{tabular}{|c|c|c|c|c|c|c|c|c|c|c|c|}
\hline Author, year & $n$ & $\begin{array}{c}\text { Male/ } \\
\text { Female }\end{array}$ & $\begin{array}{l}\text { Mean } \\
\text { Age } \\
\text { (year) }\end{array}$ & $\begin{array}{c}\text { Mean } \\
\text { follow-up } \\
\text { (month) }\end{array}$ & $\begin{array}{c}\text { Mean } \\
\text { Hb before } \\
(\mathrm{g} / \mathrm{L})\end{array}$ & $\begin{array}{c}\text { Mean } \\
\text { Hb end } \\
(\mathrm{g} / \mathrm{L})\end{array}$ & $\begin{array}{c}\text { EPO } \\
\text { treatment } \\
(\mathbf{Y} / \mathbf{N})\end{array}$ & $\begin{array}{c}\text { Mean } \\
\text { Creatinine } \\
(\mathbf{m g} / \mathrm{dl})\end{array}$ & $\begin{array}{c}\text { Number } \\
\text { of graft } \\
\text { loss }\end{array}$ & $\begin{array}{c}\text { Number } \\
\text { of all- } \\
\text { cause } \\
\text { death }\end{array}$ & $\begin{array}{c}\text { Jadad } \\
\text { score }\end{array}$ \\
\hline Al-Otaibi T (2014) $)^{13}$ & 120 & $47 / 73$ & 39.0 & 12 & $\begin{array}{l}\mathrm{G} 1: 111.0 \\
\mathrm{G} 2: 111.0\end{array}$ & $\begin{array}{l}\mathrm{G} 1: 114 \\
\mathrm{G} 2: 118\end{array}$ & $\mathrm{Y}$ & - & 4 & 4 & 3 \\
\hline Yasari F (2012) ${ }^{14}$ & 40 & $22 / 18$ & 46.9 & 6 & $\begin{array}{l}\mathrm{G} 1: 90.0 \\
\mathrm{G} 2: 88.0\end{array}$ & $\begin{array}{l}\mathrm{G} 1: 116.0 \\
\mathrm{G} 2: 112.0\end{array}$ & $\mathrm{Y}^{*}$ & 1.2 & 0 & 0 & 5 \\
\hline Choukroun G (2012) & 125 & $61 / 64$ & 48.8 & 24 & $\begin{array}{l}\mathrm{G} 1: 104.0 \\
\mathrm{G} 2: 106.0\end{array}$ & $\begin{array}{c}\mathrm{G} 1: 131.0 \\
\mathrm{G} 2: 1114.0\end{array}$ & $\mathrm{Y}^{*}$ & 2.1 & 16 & 4 & 5 \\
\hline Beiraghdar F (2012) ${ }^{16}$ & 50 & $24 / 26$ & 42.6 & 2 & $\begin{array}{l}\text { G1:83.8 } \\
\text { G2:83.0 }\end{array}$ & $\begin{array}{c}\mathrm{G} 1: 99.9 \\
\mathrm{G} 2: 97.6 .0\end{array}$ & $\mathrm{Y}$ & 3.4 & - & - & 4 \\
\hline Bartels V $(2012)^{17}$ & 40 & $17 / 23^{*}$ & 53.0 & 8 & $\begin{array}{l}\mathrm{G} 1: 109.0 \\
\mathrm{G} 2: 113.0\end{array}$ & $\begin{array}{l}\mathrm{G} 1: 126.0 \\
\mathrm{G} 2: 113.0\end{array}$ & $\mathrm{Y}^{*}$ & 1.9 & - & - & 3 \\
\hline Formica RN $(2006)^{18}$ & 56 & $34 / 22^{*}$ & 48.0 & 12 & $\begin{array}{l}\mathrm{G} 1: 105.0 \\
\mathrm{G} 2: 100.0\end{array}$ & $\begin{array}{l}\mathrm{G} 1: 122.0 \\
\mathrm{G} 2: 139.0\end{array}$ & $\mathrm{~N}$ & 2.0 & - & - & 3 \\
\hline Vanrenterghem Y $(2005)^{19}$ & 833 & $548 / 285$ & 46.3 & 6 & $\begin{array}{l}\mathrm{G} 1:<110.0 \\
\mathrm{G} 2:<110.0 \\
\mathrm{G} 3:<110.0\end{array}$ & $\begin{array}{l}\mathrm{G} 1:>120.0 \\
\mathrm{G} 2:>120.0 \\
\mathrm{G} 3:>120.0\end{array}$ & $\mathrm{~N}$ & - & 57 & 7 & 3 \\
\hline Van Biesen W (2005) $)^{20}$ & 40 & $22 / 18$ & 45.5 & 3 & $\begin{array}{l}\mathrm{G} 1: 84.0 \\
\mathrm{G} 2: 92.0\end{array}$ & $\begin{array}{l}\mathrm{G} 1: 126.0 \\
\mathrm{G} 2: 121.0\end{array}$ & $\mathrm{Y}^{*}$ & 2.7 & - & - & 3 \\
\hline De Sevaux RG $(1998)^{21}$ & 83 & $52 / 31$ & 45.0 & 24 & $\begin{array}{l}\mathrm{G} 1: 80.0 \\
\mathrm{G} 2: 80.0\end{array}$ & $\begin{array}{l}\mathrm{G} 1: 81.0 \\
\mathrm{G} 2: 85.0\end{array}$ & $\mathrm{~N}$ & 1.5 & 4 & - & 3 \\
\hline
\end{tabular}

" One group or part of the renal transplant recipients use erythropoietin. EPO, erythropoietin; G1, group 1; G2, group 2; G3, group 3; Hb, hemoglobin.

were not significant (Begg test, $P=0.458$; Egger test, $P=0.812)$.

\section{DISCUSSION}

The main finding of this meta-analysis was that anemia correction improves the outcomes in renal transplant recipients. It not only decreased the creatinine level and graft loss rate, but significantly reduced the allcause death rate.

According to the WHO classification, anemia is that hemoglobin levels of $<120 \mathrm{~g} / \mathrm{L}$ in women and $<130$ $\mathrm{g} / \mathrm{L}$ in men [22]. Most renal transplant recipients develop anemia during the early post-transplant period [23, 24]. And the presence of anemia has been associated with increased mortality, cardiovascular disease, and graft loss

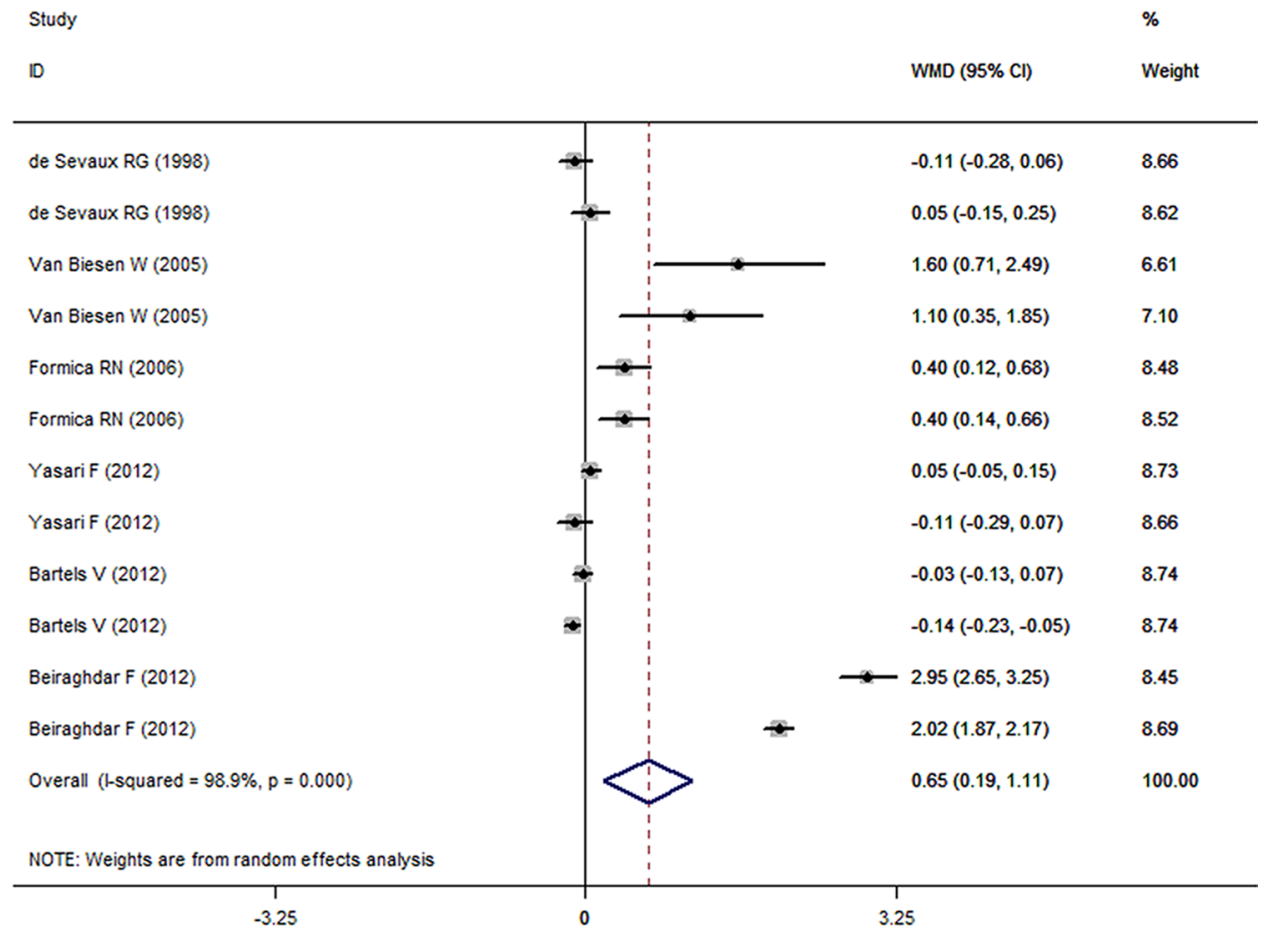

Figure 2: Creatinine level in renal transplant recipients. CI, confidence interval; WMD, weighted mean difference. 


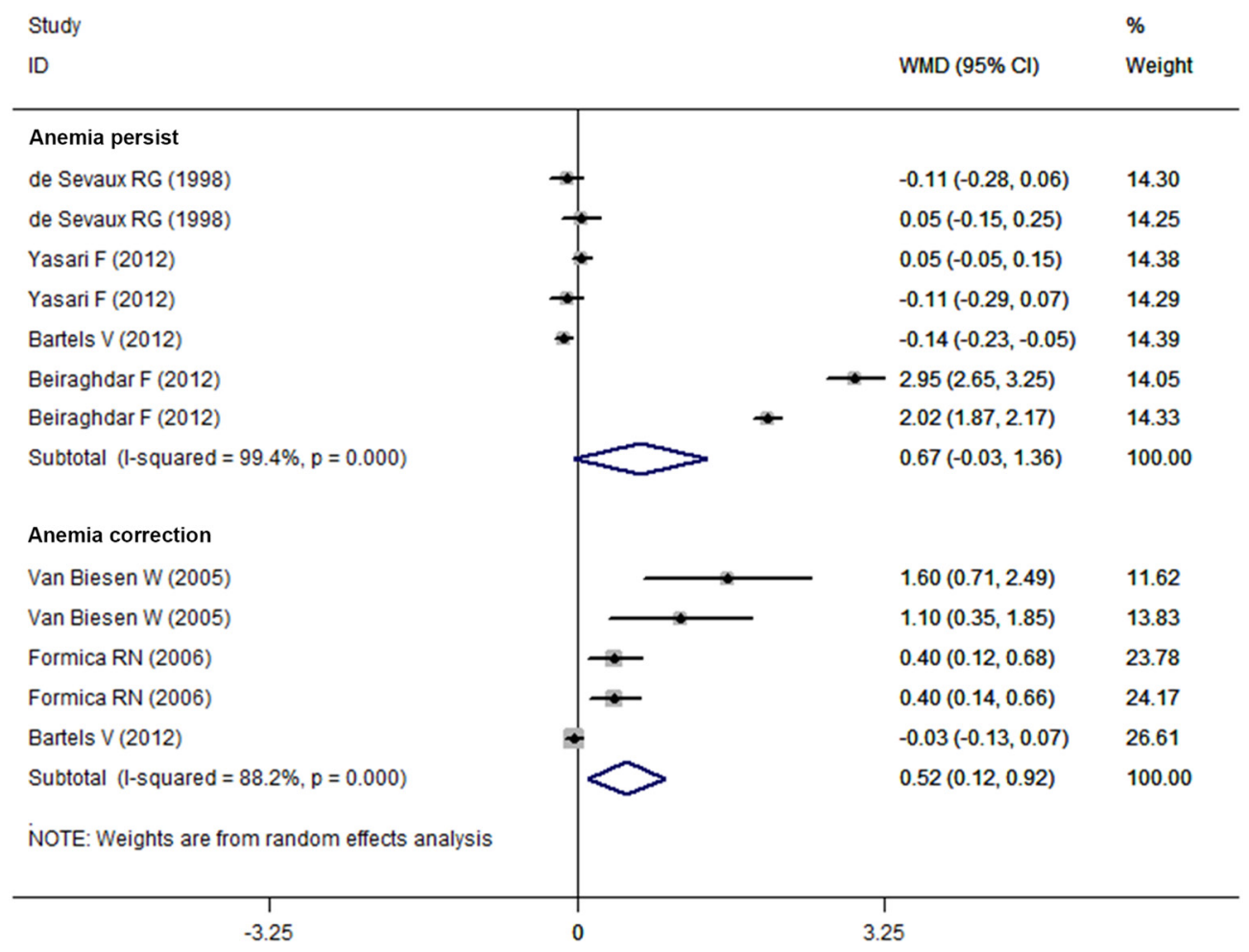

Figure 3: Anemia correction decreased creatinine level in renal transplant recipients. According to the hemoglobin level at the end of each study, two groups divided: anemia correction group (hemoglobin level $>120 \mathrm{~g} / \mathrm{L}$ ) and anemia persist group (hemoglobin level $<120 \mathrm{~g} / \mathrm{L}$ ). CI, confidence interval; WMD, weighted mean difference.

\begin{tabular}{|c|c|c|c|}
\hline \multicolumn{3}{|l|}{ Study } & \multirow{2}{*}{$\begin{array}{l}\% \\
\text { Weight }\end{array}$} \\
\hline ID & & WMD (95\% Cl) & \\
\hline \multicolumn{4}{|l|}{ EPO treatment } \\
\hline Van Biesen W (2005) & $\longrightarrow$ & $1.60(0.71,2.49)$ & 14.66 \\
\hline Formica RN (2006) & $\rightarrow$ & $0.40(0.12,0.68)$ & 16.92 \\
\hline Yasari F (2012) & + & $0.05(-0.05,0.15)$ & 17.19 \\
\hline Bartels V (2012) & & $-0.03(-0.13,0.07)$ & 17.19 \\
\hline Beiraghdar F (2012) & & $\multimap 2.95(2.65,3.25)$ & 16.89 \\
\hline Beiraghdar F (2012) & $\neq$ & $2.02(1.87,2.17)$ & 17.15 \\
\hline Subtotal $(1-$ squared $=99.4 \%, p=0.000)$ & $\Rightarrow$ & $1.15(0.27,2.03)$ & 100.00 \\
\hline \multicolumn{4}{|l|}{ Control } \\
\hline de Sevaux RG (1998) & & $-0.11(-0.28,0.06)$ & 19.61 \\
\hline de Sevaux RG (1998) & & $0.05(-0.15,0.25)$ & 18.34 \\
\hline Van Biesen W (2005) & 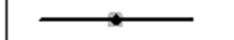 & $1.10(0.35,1.85)$ & 4.57 \\
\hline Formica RN (2006) & $\rightarrow$ & $0.40(0.14,0.66)$ & 15.66 \\
\hline Yasari F (2012) & & $-0.11(-0.29,0.07)$ & 19.31 \\
\hline Bartels V (2012) & & $-0.14(-0.23,-0.05)$ & 22.51 \\
\hline Subtotal $(1-$ squared $=80.5 \%, p=0.000)$ & > & $0.05(-0.13,0.23)$ & 100.00 \\
\hline \multicolumn{4}{|c|}{ NOTE: Weights are from random effects analysis } \\
\hline $\begin{array}{c}1 \\
-3.25\end{array}$ & & $\begin{array}{c}1 \\
3.25\end{array}$ & \\
\hline
\end{tabular}

Figure 4: Erythropoietin (EPO) treatment decreased creatinine level in renal transplant recipients. CI, confidence interval; WMD, weighted mean difference. 


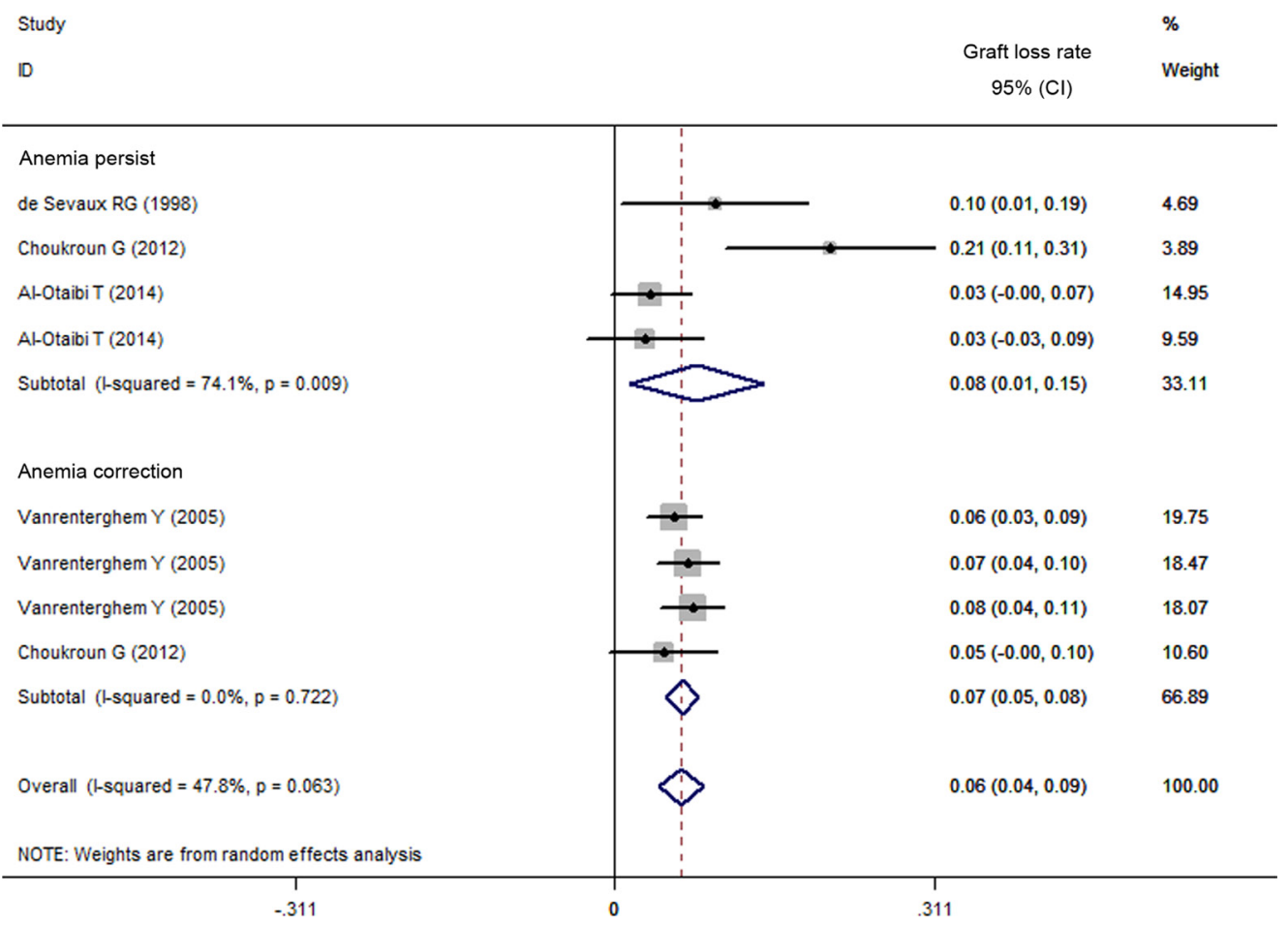

Figure 5: Graft loss rate in renal transplant recipients. According to the hemoglobin level at the end of each study, two groups divided: anemia correction group (hemoglobin level $>120 \mathrm{~g} / \mathrm{L}$ ) and anemia persist group (hemoglobin level $<120 \mathrm{~g} / \mathrm{L}$ ). CI, confidence interval.

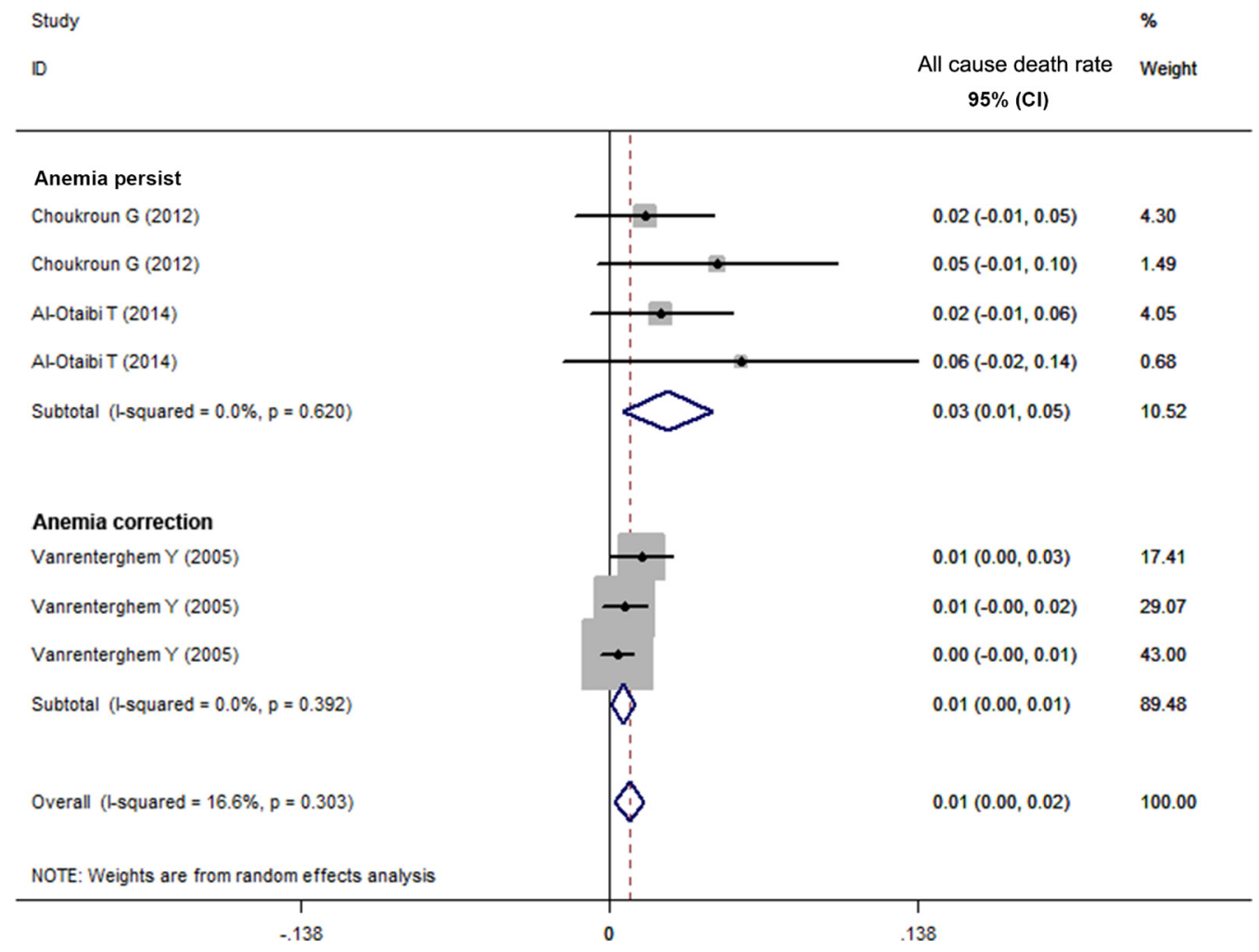

Figure 6: All-cause death rate in renal transplant recipients. According to the hemoglobin level at the end of each study, two groups divided: anemia correction group (hemoglobin level $>120 \mathrm{~g} / \mathrm{L}$ ) and anemia persist group (hemoglobin level $<120 \mathrm{~g} / \mathrm{L}$ ). CI, confidence interval. 
in renal transplant recipients [25]. In accordance with findings in previous studies, we found that renal transplant recipients with anemia correction had a significant lower graft loss rate than that with anemia persisting. Choukroun $\mathrm{G}$ et al. found that complete anemia correction was associated with a significant improvement in quality of life at 6 and 12 months after kidney transplantation. And targeting hemoglobin values $\geq 130 \mathrm{~g} / \mathrm{L}$ reduced progression of chronic allograft nephropathy in renal transplant recipients [15]. In our study, we found that even targeting hemoglobin values $\geq 120 \mathrm{~g} / \mathrm{L}$ reduced serum creatinine level, graft loss rate and all-cause death rate. More interestingly, it was found that in renal transplant recipients even if anemia was not completely corrected, increased hemoglobin level decreased creatinine level. This finding implies that anemia correction should be a standard treatment for anemic patients with kidney transplantation.

Although most studies including our study demonstrated that anemia was associated with cardiovascular events and all-cause mortality in renal transplant recipients $[4,26]$, the ALERT study showed that hemoglobin levels were not associated with any effect on cardiovascular morbidity and mortality or allcause death [5]. The possibility may be attributed to lack of adjusting risk factors, selection bias, different followup intervals $[2,5]$. Because a series of factors influence the outcomes in renal transplant recipients such as using immunosuppressive drugs, statins use, EPO treatment, and declined renal functions. In our study, we also not explored the influential factors such as anti-hypertensive drugs or
NSAIDs due to the limitation data of the enrolled studies. Further studies are needed to explore this question.

EPO treatment is a common therapy for anemia correction in renal transplant recipients. It has been demonstrated that EPO treatment is benefit for graft function for patients with kidney transplantation [8, 14]. However, it was shown that anemia correction with EPO treatment in CKD did not reduce the risk of cardiovascular events or renal events and no incremental improvement in the quality of life was found either [27, 28]. The controversy was possibly because the study designs, different participants and the type of EPO treatment. In addition, during the process of EPO treatment, hemoglobin level should be monitored. It was reported that the risk of graft thrombosis increased during the process of anemia correction with EPO treatment. According to the WHO anemia classification, hemoglobin level at $120 \mathrm{~g} / \mathrm{L}$ can be a target for EPO treatment. However, more large-scale RCTs are needed. Furthermore, in our study, we did not provide a suggested dosage of EPO because of the inconsistent dosage of EPO used in each RCT (See Supplementary Table 1). However, we found 4000-6000 IU, thrice per week, maybe suggested as a common dosage of EPO.

\section{CONCLUSIONS}

Our findings demonstrated that in renal transplant recipients, anemia correction improves the outcomes especially for graft loss and all-cause death. Furthermore, targeting hemoglobin level at least $120 \mathrm{~g} / \mathrm{L}$ with EPO treatment can be suggested as a standard therapy.

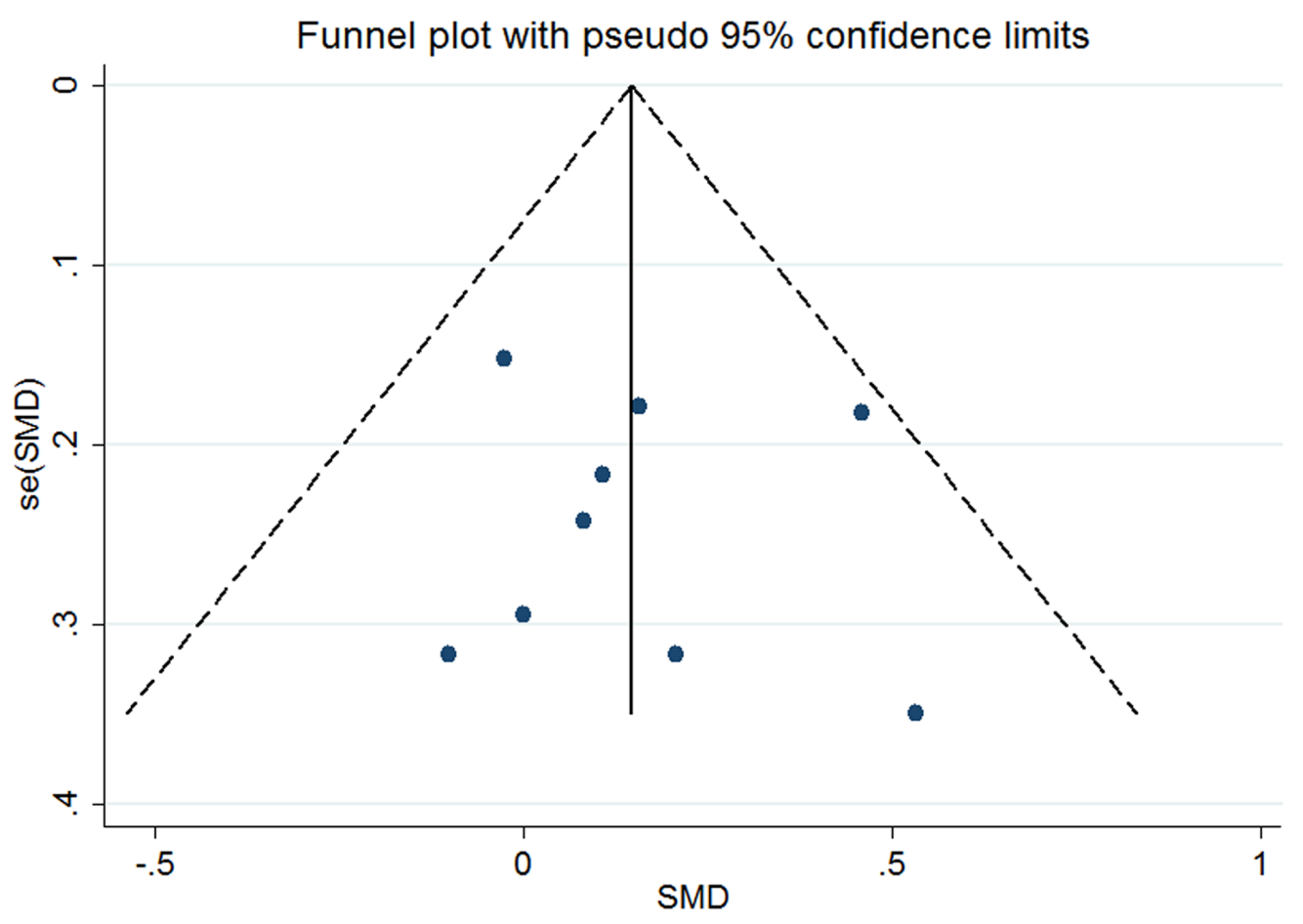

Figure 7: Funnel plot for publication bias. 


\section{ACKNOWLEDGMENTS AND FUNDING}

This work was supported by National Nature Scientific Foundation of China (81470976) and National Natural Science Fund Youth Science project (81302549).

\section{CONFLICTS OF INTEREST}

None.

\section{REFERENCES}

1. Vanrenterghem Y. Anemia after kidney transplantation. Transplantation. 2009; 87:1265-1267.

2. Vlagopoulos PT, Tighiouart H, Weiner DE, Griffith J, Pettitt D, Salem DN, Levey AS, Sarnak MJ. Anemia as a risk factor for cardiovascular disease and all-cause mortality in diabetes: the impact of chronic kidney disease. J Am Soc Nephrol. 2005; 16:3403-3410.

3. Locatelli F, Pisoni RL, Combe C, Bommer J, Andreucci VE, Piera L, Greenwood R, Feldman HI, Port FK, Held PJ. Anaemia in haemodialysis patients of five European countries: association with morbidity and mortality in the Dialysis Outcomes and Practice Patterns Study (DOPPS). Nephrol Dial Transplant. 2004; 19:121-132.

4. Molnar MZ, Czira M, Ambrus C, Szeifert L, Szentkiralyi A, Beko G, Rosivall L, Remport A, Novak M, Mucsi I. Anemia is associated with mortality in kidney-transplanted patients - a prospective cohort study. Am J Transplant. 2007; 7:818-824.

5. Schjelderup P, Dahle DO, Holdaas H, Mjoen G, Nordby G, Abedini S, Jardine A, Fellstrom B, Svensson M. Anemia is a predictor of graft loss but not cardiovascular events and allcause mortality in renal transplant recipients: follow-up data from the ALERT study. Clin Transplant. 2013; 27:E636-643.

6. Kamar N, Rostaing L, Ignace S, Villar E. Impact of posttransplant anemia on patient and graft survival rates after kidney transplantation: a meta-analysis. Clin Transplant. 2012; 26:461-469.

7. Maiorano A, Stallone G, Schena A, Infante B, Pontrelli P, Schena FP, Grandaliano G. Sirolimus interferes with iron homeostasis in renal transplant recipients. Transplantation. 2006; 82:908-912.

8. Linde T, Ekberg H, Forslund T, Furuland H, Holdaas H, Nyberg G, Tyden G, Wahlberg J, Danielson BG. The use of pretransplant erythropoietin to normalize hemoglobin levels has no deleterious effects on renal transplantation outcome. Transplantation. 2001; 71:79-82.

9. Hafer C, Becker T, Kielstein JT, Bahlmann E, Schwarz A, Grinzoff N, Drzymala D, Bonnard I, Richter N, Lehner F, Klempnauer J, Haller H, Traeder J, Fliser D. High-dose erythropoietin has no effect on short- or long-term graft function following deceased donor kidney transplantation. Kidney Int. 2012; 81:314-320.
10. Zhan X, Wang J, Pan S, Lu C. Tea consumption and the risk of ovarian cancer: A meta-analysis of epidemiological studies. Oncotarget. 2017; 8:37796-37806. https://doi. org/10.18632/oncotarget.16890.

11. Zhang K, Chen J, Liu Y, Wang T, Wang L, Wang J, Huang H. Diastolic blood pressure reduction contributes more to the regression of left ventricular hypertrophy: a metaanalysis of randomized controlled trials. J Hum Hypertens. 2013; 27:698-706.

12. Jamula E, Anderson J, Douketis JD. Safety of continuing warfarin therapy during cataract surgery: a systematic review and meta-analysis. Thromb Res. 2009; 124:292-299.

13. Al-Otaibi T, Gheith O, Halim MA, Abu Attia H, Mansour H, Said T, Nair P, Balaha M, Nampoory MR. Long-acting erythropoietin stimulating agents for persistent anemia after kidney transplant: risk factors and outcome. Exp Clin Transplant. 2014; 12:220-226.

14. Yasari F, Nafar M, Alipour Abdei B, Ahmadpoor P, Pour-Reza-Gholi F, Samadian F, Farhangi S. Effect of erythropoietin on kidney allograft survival: early use after transplantation. Iran J Kidney Dis. 2012; 6:44-48.

15. Choukroun G, Kamar N, Dussol B, Etienne I, CassutoViguier E, Toupance O, Glowacki F, Moulin B, Lebranchu Y, Touchard G, Jaureguy M, Pallet N, Le Meur Y, et al. Correction of postkidney transplant anemia reduces progression of allograft nephropathy. J Am Soc Nephrol. $2012 ; 23: 360-368$.

16. Beiraghdar F, Panahi Y, Einollahi B, Torkaman M, Mohammadi R, Marzony ET, Sahebkar A. Investigation of the efficacy of a biogeneric recombinant human erythropoietin alfa in the correction of post-transplantation anemia: a randomized comparative trial with Eprex. Clin Lab. 2012; 58:1179-1185.

17. Bartels V, Hillebrand U, Kosch M, Hausberg M, Kisters K, Di Marco GS, Reiermann S, Pavenstaedt H, Lang D. Influence of erythropoietin on arterial stiffness and endothelial function in renal transplant recipients. Am J Nephrol. 2012; 36:355-361.

18. Formica RN Jr, Friedman AL, Lorber MI, Smith JD, Eisen T, Bia MJ. A randomized trial comparing losartan with amlodipine as initial therapy for hypertension in the early post-transplant period. Nephrol Dial Transplant. 2006; 21:1389-1394.

19. Vanrenterghem Y, van Hooff JP, Squifflet JP, Salmela K, Rigotti P, Jindal RM, Pascual J, Ekberg H, Sicilia LS, Boletis JN, Grinyo JM, Rodriguez MA; European Tacrolimus/MMF Renal Transplantation Study Group. Minimization of immunosuppressive therapy after renal transplantation: results of a randomized controlled trial. Am J Transplant. 2005; 5:87-95.

20. Van Biesen W, Vanholder R, Veys N, Verbeke F, Lameire N. Efficacy of erythropoietin administration in the treatment of anemia immediately after renal transplantation. Transplantation. 2005; 79:367-368.

21. de Sevaux RG, Hilbrands LB, Tiggeler RG, Koene RA, Hoitsma AJ. A randomised, prospective study on the 
conversion from cyclosporine-prednisone to cyclosporineazathioprine at 6 months after renal transplantation. Transpl Int. 1998; 11:S322-324.

22. McLean E, Cogswell M, Egli I, Wojdyla D, de Benoist B. Worldwide prevalence of anaemia, WHO Vitamin and Mineral Nutrition Information System, 1993-2005. Public Health Nutr. 2009; 12:444-454.

23. Winkelmayer WC. Pharmacoepidemiology of Anemia in Kidney Transplant Recipients. J Am Soc Nephrol. 2004; 15:1347-1352.

24. Mix TC, Kazmi W, Khan S, Ruthazer R, Rohrer R, Pereira BJ, Kausz AT. Anemia: a continuing problem following kidney transplantation. Am J Transplant. 2003; 3:1426-1433.

25. Pankewycz O, Kulaylat M, Fagan L, Matthews B, Kohli $\mathrm{R}$, Laftavi MR. A prospective protocol-based trial of darbepoetin alfa therapy to correct the early anemia following renal transplantation. Transplant Proc. 2010; 42:3537-3541.

26. Kadambi PV, Javaid B. Cardiovascular diseases in kidney transplant recipients: the role of anemia. Adv Chronic Kidney Dis. 2004; 11:328-333.

27. Singh AK, Szczech L, Tang KL, Barnhart H, Sapp S, Wolfson M, Reddan D. Correction of anemia with epoetin alfa in chronic kidney disease. N Engl J Med. 2006; 355:2085-2098.

28. Pfeffer MA, Burdmann EA, Chen CY, Cooper ME, de Zeeuw D, Eckardt KU, Feyzi JM, Ivanovich P, Kewalramani R, Levey AS, Lewis EF, McGill JB, McMurray JJ, et al. A trial of darbepoetin alfa in type 2 diabetes and chronic kidney disease. N Engl J Med. 2009; 361:2019-2032. 